\title{
Political Abuse of Psychiatry with a Special Focus on the USSR
}

\author{
Report of a meeting held at the Royal College of Psychiatrists on 18 November 1986 \\ James FinLayson, Registrar, Craig Dunain Hospital, Inverness, Scotland
}

In an effort to give doctors in Britain a fuller picture of the political abuse of psychiatry in the USSR the College's Special Committee on the Political Abuse of Psychiatry convened a conference on 18 November 1986 . Nearly all the other Royal Colleges sent representatives. The British Medical Association, the Royal Society of Medicine, The General Medical Council, the Department of Health and Social Security, and the medical press were also represented. Dr Thomas Bewley, the President of the College, was in the chair, and three members of the Committee presented papers. Professor Kenneth Rawnsley led and summed up the discussion.

Dr Peter Sainsbury, Chairman of the Special Committee, described the Committee's work since its formation in 1977. Prior to this, there had been increasing evidence that people who are not mentally ill were being detained compulsorily in Soviet mental hospitals because they had dissented in various ways. In the 1970 s the Working Group on the Internment of Dissenters in Mental Hospitals (a Londonbased research group), along with Amnesty International, obtained clear evidence of psychiatric misuse. Following the World Psychiatric Association's (WPA) condemnation of the abuse in 1977 at their conference in Honolulu, the College set up a Special Committee. Its initial aim was to support people unjustly detained, to encourage psychiatrists to stand up to the abuse of their profession, and to try to persuade the Soviet authorities to stop the unethical practice. In 1983, due to pressure from, among others, the Royal College, the Soviet Psychiatric Society resigned from the WPA.

There has always been a risk of the Committee being seen as anti-Soviet. Dr Sainsbury, however, described other areas of concern: the disappearance of doctors, including psychiatrists, in Argentina, differing standards of psychiatric care for Blacks and Whites in South Africa, and most recently, the failure of the Japanese Government to oversee private psychiatric institutions adequately. It would appear, however, that in none of these cases had psychiatry been used as an instrument of suppression, as it had been in the USSR.

The history and extent of the problem was detailed by Dr Sidney Bloch. The method of research was described. He emphasised that by using various sources, including underground publication (Samizdat), emigré psychiatrists, the Soviet psychiatric establishment, and the victims themselves, a consistent picture had emerged. Although there is a precedent going back to pre-revolutionary times of the Russian State using psychiatry as a method of silencing its critics, it was paradoxically only in the relatively more liberal 1960 s that psychiatry came to be widely used to suppress dissent. Stalin had no compunction about killing, exiling, or putting into labour camps, anyone who disagreed with him. As the post-Stalin regime courted a respectable image in the West, dissenters were a great embarrassment. How easy to label their ideas as those of insane people! Show trials could be avoided since the defendant was "too ill to attend". Thus ill, he could only safely return to society when well, ie when he had renounced his views. In hospital, especially the Special Psychiatric Hospital, dissenters were in a harrowing environment, among genuinely disturbed patients. They could be controlled by the inappropriate prescribing of medication. They were away from the supportive comradeship enjoyed in "political" labour camps.

It is difficult to estimate the numbers involved. In one recent survey of $\mathbf{8 0 0}$ well-documented cases of political prisoners, $20 \%$ were hospitalised. Peter Reddaway and Sidney Bloch have documented some 500 cases in their book Soviet Psychiatric Abuse (Gollancz 1985). Perhaps 700 are locked away in mental institutions at any one time. Of these $\mathbf{5 0 \%}$ are human rights activists (including members of the unofficial peace movement), $10 \%$ nationalists and supporters of various ethnic groups, and $30 \%$ wouldbe emigrants. The remainder comprise religious believersOrthodox, Baptists, and even Hare Krishnas.

Only a small number of Soviet psychiatrists have openly criticised the abuse of psychiatry, and they have paid a heavy price for doing so. The most notable of these is Dr Anatoly Koryagin; as psychiatric adviser to the Moscow Committee monitoring the Helsinki Accord on Human Rights, he had examined 16 dissenters who had either been in a mental hospital or were at risk of being sent there because of their political beliefs. In 1981 he was sentenced to seven years in a labour camp and five years of internal exile. Since then he has been beaten, put in solitary confinement repeatedly, and sentenced to a further two years." The leaders of the Soviet psychiatric establishment play their part in perpetuating the practice in the hope of preserving their positions. The vast majority of Soviet psychiatrists quietly acquiesce in the oppression, perhaps trying to alleviate individual cases, but frightened to step out of line.

Dr Gary Low-Beer spoke of the many difficulties involved in trying to help end the Soviet abuses. There is no independent medical profession-everyone is a servant of the Party and the State. Soviet psychiatric nosology, in particular "sluggish schizophrenia", can be used to call reformers with their "ideas of dissent" and "Messianism" psychiatrically ill. Soviet society dislikes foreign interference, genuinely 
believing that the West is out to harm and destroy them. It is possible, however, to help. Since the 1975 Helsinki Accord, human rights in the USSR have become a legitimate concern of the West. The Soviet authorities wish to have a good public relations image, and respond to pressures for the release of individuals. Dissenters crave support from people in the West, and any doctor who has the opportunity of visiting Russia should always ensure that they see people who have suffered. The Soviets desire recognition by the international community of their scientific efforts. Contact should be made with those attending international scientific conferences from the USSR. It should be remembered however that they will be regarded as particularly trustworthy, or they would not have been granted permission to leave the country. The organisers of scientific meetings should not allow a paper to be read by a "spokesman", on the pretext that the original author was "unfortunately unwell" and therefore unable to attend. This nearly always means the original invitee is viewed with some suspicion and has been refused permission to travel.

The ensuing discussion was led by Professor Rawnsley. He gave his own initial reaction to allegations of Soviet psychiatric abuse as being the result of Western disinformation. He now realises however, that there is no doubt as to their validity. In the early 1980 s, when the Soviet authorities were under pressure from the WPA, there had been an improvement in the situation. Since the resignation of the Soviet psychiatric society from that body, he had hoped that a period out of the limelight would allow them to make further progress. The situation had worsened again, and it was as a result of this that he thought more publicity among British doctors should be achieved, so that pressure could be applied by them to end this abuse of psychiatry and indeed the whole of medicine.
Delegates to the conference expressed their thanks to the College for giving them the opportunity to learn more about the Russian situation. Some said they had not realised the extent of the problem. The degree of nonpsychiatric medical abuse was questioned. It was pointed out that although this is a reality, most often it is malpractice rather than abuse.

Personal contact was stressed as a valuable means of communication. Everyone should beware, however, that those allowed to travel are the ones with the regime's confidence. The role of the Government, in particular the Foreign Office was praised, but they needed reminding of the need for continued pressure. An interview with the new Soviet Ambassador was suggested and thought useful.

The possibility of international pressure was raised. The USSR has powerful friends and although the World Health Organisation had interested themselves in South Africa, they would probably not wish to be drawn into confrontation with the USSR.

The conference received a gratifying amount of publicity in the medical press. Hospital Doctor had an editorial, The Lancet had an informative paragraph, and the British Medical Journal a full page leading article.

In summing up the conference, Professor Rawnsley stated that he had taken heart from the evident interest of the medical profession, and their desire to change the situation in Russia, which is a disgrace to psychiatry and to medicine as a whole. He felt the time was right for continued pressure to achieve this change. This would come "trickle by trickle rather than as a sudden event".

* Dr Koryagin was released at the end of February 1987 and is now in his home town of Kharkov.

\section{Incorporation of Private Hospitals in Public Funded Training Schemes}

Following the report from the Collegiate Trainees' Committee on Manpower Control of Private Hospital Training Posts in England and Wales, Council have approved the Executive and Finance Committee's recommendation that, having accepted the need for manpower control, the College should not consider any new applications for private hospital training posts until such posts had received Regional Manpower Approval. This already occurs in new posts considered by JCHPT. The responsibility for applying for such approval would lie with the Private Hospitals.

\section{Differential in Registration Fees for Inceptors at Quarterly Meetings}

Council has approved the recommendation of the Programmes and Meetings Committee for a differential in registration fees for Inceptors at Quarterly Meetings, with a corresponding increase in fees for other Members of the College to cover the cost of this subsidy. 